\title{
"Our Age": Frederick the Great, Classical Warfare, and the Uses and Abuses of Military History
}

\author{
Adam L. Storring \\ Lichtenberg-Kolleg, Georg-August-Universität Göttingen \\ alstorring@gmail.com
}

\begin{abstract}
Whereas the long-running Military Revolution debate has focused primarily on changes in military technology and the growth of states in early modern Europe, the example of King Frederick II ("the Great") of Prussia highlights how changes in the character of war were perceived by contemporaries, and how they used narratives of change for rhetorical purposes. Frederick and his contemporaries saw their own time as more intellectually advanced than any previous age, and this narrative of intellectual progress existed alongside a narrative of states bringing order. Frederick articulated largely consistent ideas about military history, but also used concepts of the superiority of "our age" to extoll the virtues of his own oblique order of battle, and manipulated narratives of technological change to apologise for his own mistakes. Frederick also turned to an idealised classical world - particularly Julius Caesar - to envisage conquests that went beyond the limits of his own day.
\end{abstract}

\section{Keywords}

Frederick the Great - Prussian Army - Absolutism - Enlightenment - Classical Warfare - Julius Caesar - Military Revolution - Changing Character of War

\footnotetext{
- For their helpful comments on this article and the $\mathrm{PhD}$ dissertation from which it was drawn, I am grateful to Christopher Clark, Marian Füssel, Jürgen Luh, Dorinda Outram, Helen Roche, Brendan Simms, Peter Wilson, three anonymous peer reviewers, and the Enlightenment Reading Group at the Lichtenberg-Kolleg. I would also like to thank the Arts and Humanities Research Council (grant number AH/L503897/1), the Bühler-BolstorffStiftung Berlin, the Deutscher Akademischer Austauschdienst, the Leibniz-Institut für Europäische Geschichte, the Lichtenberg-Kolleg / Göttingen Institute for Advanced Study, the Stiftung Preußischer Kulturbesitz and the Stiftung Preußische Schlösser und Gärten for funding the research that made this article possible.
} 


\section{Introduction}

The long-running Military Revolution debate has focused much scholarly attention on changes in the character of war in early modern Europe, particularly developments in military technology and the tactics this fostered, and in the capacity of states to wage war. ${ }^{1}$ This article, however, uses the example of King Frederick II ("the Great") of Prussia (reigned 1740-86) to highlight the importance of considering not just actual but perceived change (or lack of change) in the character of war, and the ways in which change is presented for rhetorical purposes. ${ }^{2}$ It examines not only Frederick's own writings but also those of authors read by him - particularly military commentators such as the marquis de Feuquières (1648-1711), the chevalier de Folard (1669-1752), the marquis de Puységur (1656-1743), the marquis de Quincy (16601728), the marquis de Santa Cruz de Marcenado (1684-1732) and Maurice de Saxe (1696-1750) - as well as the works of Frederick's military intimate Karl Theophil Guichard (1724-75) and of Friedrich Moritz von Rohr, an ensign in Frederick's guard. ${ }^{3}$ It shows that Frederick and many of his contemporaries saw their own time as distinct from previous ages, both because of intellectual developments associated particularly with what is now called the "Scientific Revolution" and because of efforts by states to impose order after the disasters of religious and civil wars. They also

\footnotetext{
${ }^{1}$ Geoffrey Parker, The Military Revolution: Military Innovation and the Rise of the West, 1500-1800, $2^{\text {nd }}$ edn. with further revision (Cambridge, 2001); Michael Roberts, The Military Revolution, 1560-1660: An Inaugural Lecture Delivered before the Queen's University of Belfast (Belfast, 1956). For contrary views, see Jeremy Black, A Military Revolution? Military Change and European Society 1550-1800 (London, 1991); Jeremy Black, "Eighteenth-Century Warfare Reconsidered", War in History 1 (1994): 215-32; Andrew N. Liaropoulos, "Revolutions in Warfare: Theoretical Paradigms and Historical Evidence: The Napoleonic and First World War Revolutions in Military Affairs", The Journal of Military History 70 (2006): 363-84; David Parrott, "Had a Distinct Template for a 'Western Way of War' been Established before 1800?", in The Changing Character of War, eds. Hew Strachan and Sibylle Scheipers (Oxford, 2011), 48-60.

2 On "conceptual 'fabrications' of change and continuity", see Hew Strachan and Sibylle Scheipers, "Introduction", in The Changing Character of War, eds. Strachan and Scheipers, 14, 16-20.

${ }^{3}$ On Frederick's favourite military authors, see Großer Generalstab Kriegsgeschichtliche Abteilung II, Friedrich des Großen Anschaunngen vom Kriege in ihrer Entwickelung von 1745 bis 1756 (Berlin, 1899), 233-5, 377-9; Ullrich Marwitz, "Friedrich der Große als Feldherr", in Friedrich der Große und das Militärwesen seiner Zeit, ed. Militärgeschichtliches Forschungsamt (Herford, Bonn, 1987), 75. On Rohr, see Christopher Duffy, The Army of Frederick the Great, $2^{\text {nd }}$ edn. (Chicago, IL, 1996), 53.
} 
recognized substantial differences in military technology between their own time and previous ages. However, they disagreed just as much as modern historians do about the nature and timing of these changes and the degree to which they had invalidated the lessons of classical antiquity. Indeed, the sense of living in a distinctly different age made an idealised classical past a seductive alternative to the limitations of the present. Moreover, Frederick and other military authors were perfectly prepared to manipulate their accounts of military history, and the associated changes in the character of war, in order to suit their rhetorical purposes.

Recent years have seen a transformation in our understanding of Frederick II. Whereas historians like Friedrich Meinecke and Theodor Schieder portrayed Frederick as a contradictory figure, torn between his intellectual interests and the demands of power politics, Thomas Biskup, Jürgen Luh and Andreas Pečar have shown that the king's military, literary and cultural achievements were all part of a consistent effort by Frederick to establish his own greatness. ${ }^{4}$ Avi Lifschtiz has emphasized that Frederick's writings presented a consistent political philosophy that reflected broader contemporary trends, but noted that Frederick's ideas were "far from ... self-denying" and could even be seen as "self-seeking". This article shows that Frederick similarly articulated relatively consistent ideas about military history and his own place within it, but that his accounts were also deeply self-serving and could be opportunistic and even contradictory, as the king manipulated contemporary ideas of change in military affairs and altered his account of military history in order to represent himself to best advantage.

Christopher Clark argued that Frederick II had a "timeless" view of history, and that he was particularly attracted to the "distant past" of classical antiquity, but the example of military history shows that Frederick also followed contemporary

\footnotetext{
${ }^{4}$ Thomas Biskup, Friedrichs Größe. Inszenierung des Preußenkönigs in Fest und Zeremoniell 1740-1815 (Frankfurt am Main, New York, 2012); Jürgen Luh, Der Große. Friedrich II. von Preussen (Munich, 2011); Friedrich Meinecke, Machiavellism: The Doctrine of Raison d'Etat and its Place in Modern History, trans. Douglas Scott (London, 1957), 274-339; Andreas Pečar, Die Masken des Königs. Friedrich II. von Preußen als Schriftsteller (Frankfurt am Main, New York, 2016); Theodor Schieder, Friedrich der Große. Ein Königtum der Widersprüche (Frankfurt am Main, 1983).

5 Avi Lifschitz, "Introduction", in Frederick the Great's Philosophical Writings, ed. Avi Lifschitz, trans. Angela Scholar (Princeton, NJ, and Oxford, 2021), vii-xlii (quotations, xviii, xlii); Avi Lifschitz, "Philosophy and Political Agency in the Writings of Frederick II of Prussia”, The Historical Journal 64 (2021): 533-56 (quotations: 538, 556).
} 
ideas that sharply differentiated his own time from all previous ages. ${ }^{6}$ There was widespread belief that the early to mid- $17^{\text {th }}$ century had seen the inauguration of a new, more enlightened age, associated particularly with Francis Bacon, René Descartes and the "new philosophy" (the so-called "Scientific Revolution"). While many intellectuals portrayed "our age" ("nostre siècle": the French word "siècle" could be translated either as a "century" or as an "age") as building on the previous great civilizations of ancient Greece, Rome and the Renaissance, the "Quarrel of the Ancients and Moderns" in late $17^{\text {th }}$-century France saw the "moderns" argue that "our age" - specifically the age of King Louis XIV of France (reigned 1643-1715) - was more advanced than any that had gone before, and Frederick used such arguments to present his own military ideas to best advantage. ${ }^{7}$

Reinhard Koselleck argued that many Europeans in the long $18^{\text {th }}$ century (the period roughly from the mid $17^{\text {th }}$ century until the French Revolution) saw their own time as distinct from past ages but without any notion of "progress" toward the future. ${ }^{8}$ Frederick's portrayal of military history is a reminder that many European monarchs of the period in fact drew on powerful narratives of progress, although figures like Frederick and Louis XIV portrayed themselves as the culmination of this progress - a veritable "end of history" - rather than claiming to pave the way for future developments. ${ }^{9}$ Crucially, the narrative of intellectual progress existed alongside a separate but related narrative of order, with states presenting themselves as ending the chaos of religious and civil war. ${ }^{10}$

Frederick also offers important perspectives on the place of the classics within European military thought. Azar Gat and Armstrong Starkey have noted that the $18^{\text {th }}$

\footnotetext{
${ }^{6}$ Christopher Clark, Time and Power: Visions of History in German Politics, from the Thirty Years' War to the Third Reich (Princeton, NJ, and Oxford, 2019), 2, 15-16, 72-117, 211-4, 216 (quotations, 99, 103, 106, 111-113).

${ }^{7}$ Dan Edelstein, The Enlightenment: A Genealogy (Chicago, IL, and London, 2010) (quotation, 40); Nicole Ferrier-Caverivière, L'image de Louis XIV dans la littérature française de 1660 à 1715 (Paris, 1981), 354-6, 360, 365-9; Larry F. Norman, The Shock of the Ancient: Literature \& History in Early Modern France (Chicago, IL, and London, 2011); Steven Shapin, The Scientific Revolution, Paperback edn. (Chicago, IL, and London, 1998), 3, 5; Voltaire, Le siècle de Louis XIV, 2 vols. (Berlin, 1751), Vol. I, 1-5. On the meaning of "siècle", see Joan DeJean, Ancients Against Moderns: Culture Wars and the Making of a Fin de Siècle (Chicago, IL, and London, 1997), 2, 18-23, 151-2.

${ }^{8}$ Reinhart Koselleck, Futures Past: On the Semantics of Historical Time, trans. Keith Tribe (Cambridge, MA, and London, 1985), 3-20 (quotation, 17).

${ }^{9}$ On this phenomenon in the case of Louis XIV, see DeJean, Ancients against Moderns, ix-x, 16-17, 19-20, 79; Ferrier-Caverivière, L'image de Louis XIV, 371-3.

${ }^{10}$ On this phenomenon, see Edelstein, The Enlightenment, 35; Norman, Shock of the Ancient, 11.
} 
century saw differing views about the relevance of ancient examples for contemporary warfare, and this article shows that Frederick's approach to classical military history in some cases simply reflected his rhetorical needs in a particular situation. ${ }^{11}$ Larry Norman has noted that many Europeans in the $17^{\text {th }}$ and $18^{\text {th }}$ centuries saw the classical past as "a fundamentally foreign world", but that it was precisely "the remoteness of antiquity" that could make classical examples attractive. "Ancient works", Norman noted, were "alien enough to provide alternative models, and yet relevant enough to provide at least partially accessible models". ${ }^{12}$ Historians have noted that Johann Joachim Winckelmann, who inspired philhellenism in Germany in the later $18^{\text {th }}$ century, created an "ancient Greece of the German imagination [that] existed neither as Athens, nor Sparta, nor any other historical citystate, but rather as a sort of composite dream-world". ${ }^{13}$ In the same way, Frederick while situating his battle tactics within "our age" - looked on the strategic level to an idealised version of the ancient world as a means to achieve conquests that were scarcely possible in his own time.

\section{An Age of Order}

Frederick portrayed his age as defined by the destruction of the European religious and civil wars, notably the Thirty Years War (1618-48). While Frederick's Memoir to Serve as the History of the House of Brandenburg started with the earliest Brandenburg rulers, Frederick wrote that Hohenzollern history was only of interest from the reign of Elector John Sigismund (1608-1619), who had added Cleves and East Prussia to the Hohenzollern dominions. Dismissing the reigns of electors Frederick I (reigned 1415-40) and Albert Achilles (reigned 1471-86), Frederick argued that, "the Thirty Years War is much more interesting". ${ }^{14}$ In 1718 , Frederick's

\footnotetext{
${ }^{11}$ Azar Gat, The Origins of Military Thought from the Enlightenment to Clausewitz (Oxford, 1989), 7-8; Armstrong Starkey, War in the Age of Enlightenment, 1700-1789 (Westport, CT, London, 2003), 8-9, 22, 34-8, 51, 56, 60, 211. For the comparable situation during the Renaissance, see Parker. The Military Revolution, 6.

${ }^{12}$ Norman, Shock of the Ancient, (quotations, 5, 14, 16-17).

${ }^{13}$ Helen Roche, "The Peculiarities of German Philhellenism", The Historical Journal 61 (2018): 545.

${ }^{14}$ Johann D. E. Preuss, ed. Euvres de Frédéric le Grand, 30 vols. (Berlin, 1846-56) [henceforth Euvres], Vol. I, L.
} 
father, King Frederick William I (reigned 1713-40) instructed Frederick's tutor only to teach him in detail the history of the past 150 years, and in 1717 he had given similar instructions for the education of the orphaned son of Major General von Albe, saying that the boy should learn the history of the past hundred years (i.e. since the outbreak of the Thirty Years War). ${ }^{15}$ Frederick's own 1751 instructions for the education of the future King Frederick William II laid down that the prince was to learn ancient history, and modern history from Charlemagne onwards, but told his tutor Major Borcke to "go into greater detail only at the Thirty Years War". ${ }^{16}$ Feuquières, Frederick's favourite military author, similarly began his survey of European power politics in the year 1666, and refused to discuss the French Wars of Religion (1562-98) or the noble revolt of the Fronde (1648-53), although he did cite the English Civil Wars (1642-51). ${ }^{17}$

Even in 1945, many Germans still considered the Thirty Years War the most devastating conflict in their history. At least 15 per cent (and perhaps fully a third) of the population of the German lands died during the war, with the population only recovering to pre-1618 levels in the 1710s. Among the Hohenzollern territories, the population of Pomerania fell by $40 \%$, while the urban population of Brandenburg declined from 113,500 to 34,000 , the rural population from 300,000 to $75,000{ }^{18}$ As Frederick described it, "all the scourges of the universe fell at the same time on this unfortunate electorate [Brandenburg]". ${ }^{19}$

Frederick's emphasis on this conflict was not surprising, for the religious and civil wars provided an important justification for the stronger, more centralized government that was slowly introduced in many European states during the $17^{\text {th }}$ century, as rulers and states promised to ensure order to prevent such catastrophes happening again. ${ }^{20}$ Frederick's favourite book, Voltaire's Henriade, described how

\footnotetext{
${ }^{15}$ Friedrich Cramer, ed., Zur Geschichte Friedrich Wilhelms I. und Friedrichs II. Könige von Preußen, $3^{\text {rd }}$ edn. (Leipzig, 1835), 14; Friedrich-Karl Tharau, Die geistige Kultur des preußischen Offiziers von 1640 bis 1806 (Mainz, 1968), 66, 73-4.

${ }^{16}$ Euvres, Vol. IX, 41-2.

${ }^{17}$ Antoine de Pas, marquis de Feuquières, Mémoires, new edn. (London, 1736), 11-12, 123. On Frederick's preference for Feuquiéres, see Max Jähns, Geschichte der

Kriegswissenschaften vornehmlich in Deutschland, 3 vols. (Munich and Leipzig, 1889-91), Vol. II, 1469-73.

${ }^{18}$ Peter H. Wilson, Europe's Tragedy: A History of the Thirty Years War (London, 2009), 46, 787-95.

${ }^{19}$ Oeuvres, Vol. I, 36.

${ }^{20}$ Peter H. Wilson, Absolutism in Central Europe (London and New York, 2000), 11-12, 15 16, 18, 35, 52-3, 60; Wilson, Europe's Tragedy, 807-11.
} 
France was devastated by the "Discord" of the Wars of Religion, and portrayed the conflict particularly as a threat to legitimate authority. ${ }^{21}$ Frederick noted that Louis XIV had lived through the Fronde in his youth just as Frederick William the Great Elector (reigned 1640-88) saw the devastation of Brandenburg in the Thirty Years War, and he described both rulers as working to re-establish royal authority within their domains. ${ }^{22}$

Across Europe, ideas of state intervention to ensure a well-ordered society were expressed through the concept of "police" ("Policey" in contemporary German). ${ }^{23}$ Frederick wrote of "the infinite distance . . . between a policed people and a barbarous people", thus presenting order as an important element in civilization. ${ }^{24}$ Such ideas not only distinguished Europe from other parts of the world - Frederick emphasized the difference between "a savage of Canada" and "some citizen of a policed country of Europe" - but also designated some parts of Europe as "policed" and others as not. After visiting the Polish territory he had acquired through the First Partition of Poland (1772), Frederick declared that he had gone there in order "to reform barbarous laws ... and to establish some police in a country where the name itself was unknown". ${ }^{25}$ Contemptuously describing the inhabitants of the Habsburg domains of Bohemia and Moravia as "half savage", Frederick in contrast celebrated his own province of Silesia as "a policed country" ("un pays policé"). ${ }^{26}$

The memory of the religious and civil wars was also an important justification for the standing armies that developed in the second half of the $17^{\text {th }}$ century. The

\footnotetext{
${ }^{21}$ Arnold Berney, Friedrich der Grosse. Entwicklungsgeschichte eines Staatsmannes (Tübingen, 1934), 61; Peter Gay, Voltaire's Politics: The Poet as Realist (Princeton, NJ, 1959), 42, 98-9; Cuvres, Vol. VIII, 59-61; Cuvres, Vol. XXI, 10; Voltaire, La Henriade, new edn. (London, 1730). On the Henriade as Frederick's favourite book see, Adam L. Storring, Frederick the Great and the Meanings of War, 1730-1755, Unpublished PhD Dissertation (Faculty of History, University of Cambridge, 2017, https://www.repository.cam.ac.uk/handle/1810/277782), 87.

${ }^{22}$ CEuvres, Vol. I, 107.

${ }^{23}$ Karl Härter, ed., Policey und frühneuzeitliche Gesellschaft (Frankfurt am Main, 2000); Alexandre Mendes Cunha, "A Previously Unnoticed Swiss Connection in the Dissemination of Cameralist Ideas during the Second Half of the Eighteenth Century", History of Political Economy 49 (2017): 497-529; Marc Raeff, The Well-Ordered Police State: Social and Institutional Change Through Law in the Germanies and Russia, 1600-1800 (New Haven, CT, and London, 1983); Keith Tribe, Governing Economy: The Reformation of German Economic Discourse, 1750-1840 (Cambridge, 1988), 28-34.

${ }^{24}$ Euvres, Vol. IX, 197. See also Euvres, Vol. VIII, 100, 227; Euvres, Vol. XX, 323.

${ }^{25}$ Quotations Euvres, Vol. IX, 199; Euvres, Vol. XXIII, 293. See also Euvres, Vol. II, 37; Euvres, Vol. IX, 144; Euvres, Vol. XIII, 51; Euvres, Vol. XXIII, 114, 314; Euvres, Vol. XXVI, 407.

${ }^{26}$ Euvres, Vol. XXVI, 526.
} 
Great Elector for instance used the experience of the Thirty Years War to argue for the "necessity" of maintaining a permanent standing army. ${ }^{27}$ In 1770 , responding to Baron d'Holbach's Essay on Prejudices, Frederick maintained that it was because "France maintains great armies" that "she is no longer exposed to those times of confusion and unrest when she tore herself apart through civil wars". ${ }^{28}$

The religious and civil wars had been particularly notable for depredations by soldiers against civilians, and states and rulers of the long $18^{\text {th }}$ century promised to end this through ordered and disciplined armies. ${ }^{29}$ In his 1740 Refutation of the Prince of Machiavelli, Frederick emphasized the difference between the armies of his own time, contained by "discipline and good order", and the "mass of bandits" of the era of Machiavelli, "who usually lived only on violence and rapine". ${ }^{30}$ In his 1770 Examination of the Essay on Prejudices, Frederick extolled the standing armies of his own day as greatly preferable to "the ancient usage of hastily arming the peasants when a neighbour appeared threatening, of maintaining this militia by rapine and brigandage without assigning it regular pay, and dismissing it at the [conclusion of] peace". 31

The dating of this age of order remained flexible, however. In his 1780 treatise On German Literature, the Faults for Which One Can Reproach it, What are the Causes, and by What Means One Can Correct Them, Frederick wrote that not only had the Wars of Religion and Thirty Years War held back the development of the arts in France and Germany respectively but the Holy Roman Empire's succeeding wars against France and the Ottomans had continued to hinder its cultural development. "It was therefore only after the War of [the Spanish] Succession [1701-14] that we began to repair what so many successive calamities had caused us to lose." ${ }^{, 32}$ While the early $18^{\text {th }}$ century had indeed seen a blossoming of princely palace-building and patronage of the arts in Germany, this had already begun in the late $17^{\text {th }}$ century, as Frederick well knew from the example of his own grandfather King Frederick I (reigned 16881713) and his wife Queen Sophia Charlotte (1668-1705). ${ }^{33}$ By manipulating the

\footnotetext{
${ }^{27}$ Clark, Time and Power, 2, 15, 19-71, 211-2, 214, 216, 224-5.

${ }^{28}$ Euvres, Vol. IX, 169.

${ }^{29}$ Wilson, Europe's Tragedy, 789-92, 808.

${ }^{30}$ Euvres, Vol. VIII, 78, 197-8.

${ }^{31}$ Euvres, Vol. IX, 173.

${ }^{32}$ Euvres, Vol. VII, 109-11 (quotation, 110).

${ }^{33}$ Rolf Toman, ed., Baroque: Architecture, Sculpture, Painting, trans. Paul Aston, Phil Greenhead, Christine Shuttleworth (Königswinter, 2004), 184, 196-9.
} 
chronology, Frederick wrote his grandfather out of the narrative, thus emphasizing his own role in sponsoring cultural development in Germany. ${ }^{34}$

Gerhard Oestreich noted that this search for order substantially drew on ancient examples, and indeed numerous authors read by Frederick honoured Roman military discipline as the fore-runner of their age's disciplined armies. ${ }^{35}$ Frederick's intimate Guichard described the Romans as one of "the policed nations" ("nations policées"), and the king himself described ancient Greece as "the first policed country in the world". ${ }^{36}$ In the opening paragraph of his 1748 General Principles of War, Frederick echoed Publius Vegetius Renatus - the classic source on ancient methods of military organisation - as he maintained that, "the Roman discipline lives on only with us". ${ }^{37}$ In his 1755 Thoughts and General Rules for War, Frederick again compared the Prussian soldiers to Roman legionaries, as they were "formed and trained for battles" whereas the Austrians were superior in irregular troops. ${ }^{38}$ In 1758 , Frederick similarly began his Reflections on Tactics and on Certain Parts of War, or Reflections on Certain Changes in the Manner of Making War with a reference to one of the maxims of Vegetius. ${ }^{39}$ Frederick and his contemporaries thus saw their ordered age and way of warfare as a return to classical and especially Roman precedents.

\footnotetext{
${ }^{34}$ On Frederick II's portrayal of Frederick I, see Andreas Pečar, "Selbstinszenierung auf Kosten der Dynastie? Friedrich II. als Autor der "Denkwürdigkeiten des Hauses Brandenburg"', in Friedrich der Große und die Dynastie der Hohenzollern: Beiträge des fünften Colloquiums in der Reihe „Friedrich300“ vom 30. September / 1. Oktober 2011, eds. Michael Kaiser and Jürgen Luh (http://www.perspectivia.net/content/publikationen/friedrich300-colloquien/friedrichdynastie/pecar_geschichtsschreibung, last accessed 17 June 2021), paragraphs 22-5.

${ }^{35}$ Raimondo Montecuccoli, Mémoires, new edn. (Paris, 1746), pp. 8-10, 21; Charles-Louis de Secondat, Baron de Montesquieu, Considérations sur les causes de la grandeur des Romains et de leur décadence, $2^{\text {nd }}$ edn. (Amsterdam, 1735), 17-19; Gerhard Oestreich, Neostoicism and the Early Modern State, eds. Brigitta Oestreich and H. G. Koenigsberger, trans. David McLintock (Cambridge etc., 1982), passim (esp. 4-9); Gerhard Oestreich, Antiker Geist und moderner Staat bei Justus Lipsius (1547-1606). Der Neustoizismus als politische Bewegung, ed. Nicolette Mout (Göttingen, 1989), 39-41; Marquis de Santa Cruz de Marcenado, Réflexions militaires et politiques, trans. de Vergy, 4 vols. (The Hague, 1739), Vol. I, 237, 309, 314, 319; René Aubert de Vertot, Histoire des révolutions arrivées dans le gouvernement de la République romaine, $3^{\text {rd }}$ edn., 3 vols. (The Hague, 1724), Vol. II, 295, 301.

${ }^{36}$ Karl Theophil Guichard, Mémoires critiques et historiques sur plusieurs points d'antiquités militaires, 4 vols. (Berlin, 1774), Vol. I, xii; CEuvres, Vol. XXIV, 327.

${ }^{37}$ Euvres, Vol. XXVIII, 3. See also Euvres, Vol. I, 223; CEuvres, Vol. VI, 105; CEuvres, Vol. XXVIII, 100.

${ }^{38}$ Euvres, Vol. XXVIII, 142.

${ }^{39}$ Euvres, Vol. XXVIII, 169. See Frederick's reference to the same maxim in Gustav Berthold Volz, ed., Die politischen Testamente Friedrichs des Grossen (Berlin, 1920), 81.
} 


\section{3. "Our Age"}

In his 1753 introduction to an Extract of the work of the chevalier de Folard, which he commissioned for his officers, Frederick declared that:

The art of war . . still lacks classic books. We have few. Caesar, in his Commentaries, teaches us little more than what we see in the war of pandours [Croatian irregulars]; his expedition to Great Britain is nothing else. A general nowadays could only make use of the disposition of his cavalry on the day of Pharsalus. There is nothing to profit from all the wars that were fought in the time of the later [Roman] empire. We see the military art reborn during the troubles in Flanders [the Dutch Revolt (1566-1648)], and Turenne, a pupil of Prince Maurice of Orange [15671625], learned there this art that had been neglected for so many centuries. $^{40}$

In his 1748 General Principles of War, Frederick had similarly declared that:

The ruses the ancients used in war have become the domain of light troops. Some make ambushes; some attract their enemies by a simulated flight into defiles to cut them to pieces. Modern generals are hardly ignorant enough to fall into these kinds of crude ambushes. ${ }^{41}$

Indeed, Frederick's writings had very little to say about ancient battle tactics. He often mentioned the battle of Thermopylae (480 BC), focusing particularly on the strategic importance of the mountain pass defended by the Greeks and on the courage of King Leonidas and his Spartans. ${ }^{42}$ The Prussian king, however, said little about the other battles of the Greco-Persian Wars, and did not describe the tactics used in any of the

\footnotetext{
${ }^{40}$ Extrait tiré des Commentaires du chevalier Folard sur l'Histoire de Polybe, pour l'usage d'un officier (Berlin, 1753), 3-4.

${ }^{41}$ Euvres, Vol. XXVIII, 50.

${ }^{42}$ CEuvres, Vol. III, 78-9; CEuvres, Vol. V, 54, 254-5; Euvres, Vol. VIII, 22-3, 111, 242;

Euvres, Vol. X, 154, 276; Cuvres, Vol. XI, 99.
} 
battles of Alexander the Great, Hannibal or Scipio Africanus. ${ }^{43}$ This was despite the fact that these battles potentially offered numerous lessons for Frederick's own tactics. Alexander, Hannibal and Scipio all used outflanking manoeuvres, as Frederick did, and the former two used cavalry to deal decisive blows just as the Prussian army did in the Seven Years War (1756-63) in particular. ${ }^{44}$ The most striking omission was of the Theban general Epaminondas (418-362 BC) and his victory over the Spartans at Leuctra in $371 \mathrm{BC}$, won using precisely the oblique line tactic that Frederick came to favour, with the attack concentrated against just part of the enemy line. ${ }^{45}$ Apart from one reference to the unusually deep column formation employed by the Thebans, Frederick scarcely referred to Leuctra at all, and certainly not to support his own tactical ideas. ${ }^{46}$

This silence on the tactics of ancient battles certainly did not reflect a lack of knowledge on Frederick's part. Alongside his wide reading of actual classical authors, he also particularly liked the ancient histories of Charles Rollin (1661-1741), and the works of René-Aubert Vertot (1655-1735) and Montesquieu on Roman history. ${ }^{47}$

\footnotetext{
${ }^{43}$ For Frederick's (brief) references to the battles of Marathon (490 BC), Salamis (480 BC), Plataea (479 BC), Granicus (334 BC), Gaugamela (331 BC), Cannae (216 BC) and Zama (202 BC), see Euvres, Vol. II, xiii; CEuvres, Vol. VIII, 20, 97, 222; Euvres, Vol. IX, 155, 262, 266; Euvres, Vol. X, 268; Euvres, Vol. XII, 3, 65; Euvres, Vol. XVIII, 135; CEuvres, Vol. XX, 152; Euvres, Vol. XXIII, 165; Euvres, Vol. XXVI, 201; Politische Correspondenz Friedrich's des Grossen, 46 vols. (Berlin, 1879-1939), Vol. XX, 509. The battles of Issus (333 BC), Trebbia (218 BC) and Trasimene (217 BC) were not mentioned at all.

${ }^{44}$ On Prussian cavalry tactics, see John Childs, Armies and Warfare in Europe, 1648-1789 (Manchester, 1982), 126-7; Jürgen Luh, Kriegskunst in Europa 1650-1800 (Cologne, Weimar, Vienna, 2004), 155; Hew Strachan, European Armies and the Conduct of War (London, 1983), 17-18.

${ }^{45}$ For Leuctra, see John Buckler, The Theban Hegemony, 371-362 B.C. (Cambridge, MA, and London, 1980), 62-5; Peter Connolly, Greece and Rome at War (London, 1988), 50-1.

${ }^{46}$ Euvres, Vol. XIII, 113-14; Euvres, Vol. XXV, 275; Euvres, Vol. XXVII_I, 438. This is in contrast to the claims of Martin van Creveld noted by Donald A. Neill, "Ancestral Voices: The Influence of the Ancients on the Military Thought of the Seventeenth and Eighteenth Centuries", The Journal of Military History 62 (1998): 518. For Frederick on the Theban phalanx more generally, see Euvres, Vol. X, 268.

${ }^{47}$ C. Dantal, Les Délassemens littéraires ou Heures de lecture de Frédèric II (Elbing, 1791), 15-27, 29-33, 35, 42-4; Gonthier-Louis Fink, "Die literarischen Beziehungen Friedrichs zu Frankreich", in Panorama der fridericianischen Zeit. Friedrich der Grosse und seine Epoche. Ein Handbuch, ed. Jürgen Ziechmann (Bremen, 1985), 243-4, 246; Hans-Joachim Gehrke, "Klassische Studien. Paradoxien zwischen Antike und Aufklärung", in Friedrich der Große in Europa. Geschichte einer wechselvollen Beziehung, eds. Bernd Sösemann and Gregor Vogt-Spira, 2 vols. (Stuttgart, 2012), Vol. I, 113-26; Reinhold Koser, ed., Briefwechsel Friedrichs des Großen mit Grumbkow und Maupertius (1731-1759) (Leipzig, 1898), 127, 132-3; Bogdan Krieger, Friedrich der Große und seine Bücher (Berlin and Leipzig, 1914), 11, 15, 17-18, 37-8; Bogdan Krieger, Frederick the Great and his Books (New York, 1913), 12, 18-19, 21; Euvres, Vol. II, 42; Euvres, Vol. VII, 124.
} 
Rollin for instance described Alexander's battles in detail, and Frederick is known to have read the Greek historian Polybius, the most important chronicler of the campaigns of Hannibal and Scipio. ${ }^{48}$ Frederick quoted anecdotes from Alexander's campaigns, described Hannibal's skilful manoeuvres when crossing the river Rhône in 218 BC, noted Archimedes' efforts to foil the Roman siege of Syracuse in 213-212 BC, and discussed Hannibal's use of the Italian town of Capua as a base during the Second Punic War (218-201 BC). ${ }^{49}$ In 1736, the Saxon diplomat Ernst Christoph von Manteuffel told Frederick in detail about the Roman general Quintus Fabius Maximus (c.280-203 BC), and Frederick clearly understood Fabius's famous tactics of avoiding battle against Hannibal because he used the comparison to mock his opponent Leopold von Daun during the Seven Years War. ${ }^{50}$

The idea that the ancient art of war had been rediscovered in the age of Maurice of Orange - a "military renaissance", as Robert Quimby called it - was a commonplace at the time and indeed since. ${ }^{51}$ Puységur indeed argued that the military theory of his own day had still not equalled that of the classical period, and presented his own work as finally achieving this. ${ }^{52}$

In almost completely neglecting classical battle tactics, however, Frederick was seeking not to equal the ancients but to surpass them. In his writings, the Prussian king followed the idea of successive great ages of civilization, praising the importance given to the sciences in "our enlightened age" ("notre siècle éclairé"), differentiating the modern approach to the sciences from that of the ancients, and noting Gottfried Wilhelm Leibniz and Isaac Newton among the great men of "our age" ("notre siècle"). ${ }^{53}$ Frederick's neglect of ancient battle tactics reflected the claims of

\footnotetext{
${ }^{48}$ Charles Rollin, Histoire ancienne des Égyptiens, des Carthaginois, des Assyriens, des Babyloniens, des Mèdes et des Perses, des Macédoniens, des Grecs, 13 vols. (Amsterdam, 1730-9), Vol. VI, 183-9, 215-30, 317-8, 322-34. For Frederick reading Polybius, see Dantal, Délassemens littéraires, 18.

${ }^{49}$ Euvres, Vol. I, 12-13; Cuvres, Vol. VIII, 97; Euvres, Vol. X, 40, 71, 290, 306-7, 316; Euvres, Vol. XI, 61; Euvres, Vol. XIX, 405; Cuvres, Vol. XXIII, 309.

${ }^{50}$ Euvres, Vol. XIX, 116; Cuvres, Vol. XXIII, 72; Cuvres, Vol. XXV, 476-7; Politische Correspondenz, Vol. XVII, 235, 257. For further discussion of Fabius by Frederick, see Euvres, Vol. VIII, 173, 324; Euvres, Vol. X, 276, 279, 283; Euvres, Vol. XVII, 343; Euvres, Vol. XXVII_I, 347; Euvres, Vol. XXVII_II, 68.

${ }^{51}$ Robert S. Quimby, The Background of Napoleonic Warfare: The Theory of Military Tactics in Eighteenth-Century France (New York, 1957), 111.

52 Jacques-François de Chastenet de Puységur, Art de la guerre par principes et par règles, 2 vols. (Paris, 1748), Vol. I, 1-3, 35-8, 50.

${ }^{53}$ Clark, Time and Power, 74, 85-6, 96, 112, 115, 214; Euvres, Vol. VII, 34, 41, 113, 136-7 (quotation, 41); Euvres, Vol. IX, 264-5 (quotation, 264).
} 
"moderns" that "our age" was more advanced than any that had gone before.

Johannes Kunisch noted that Frederick's words reflected "the self-satisfied certainty that his age, so proud of its intellect, had been the first successfully to produce an art of war bounded by reason". ${ }^{54}$ In 1774, Frederick's intimate Guichard argued that the military Renaissance was out-dated, noting that "there was an epoch when in effect the ancients were our sole masters in the art of war", but arguing that this had only been necessary to escape "the ignorance of barbarous centuries". ${ }^{55}$ Rohr referred to the "changes which have gradually taken place, until the art of war has reached the perfection ("Vollkommenheit") in which it now finds itself". 56

Frederick was hugely influenced by Voltaire's book The Age of Louis XIV, which described the cultural flowering in France under the reign of the Sun King. Frederick's programme of cultural patronage throughout his reign aimed to create his own "age of Louis XIV" (or "age of Frederick"), and this also had a military dimension, reflecting France's status as the greatest military power of the long $18^{\text {th }}$ century. In contrast to his scanty mentions of classical battle tactics, Frederick's writings were full of discussion of battles of the age of Louis XIV. Whereas Frederick said nothing about Epaminondas's oblique line tactic at Leuctra, he repeatedly mentioned the outflanking manoeuvre of Henri de La Tour d'Auvergne, vicomte de Turenne (1611-75) at the 1675 battle of Turckheim, and described in detail the victory of François-Henri de Montmorency, duc de Luxembourg (1628-95), again using an outflanking manoeuvre, at the 1690 battle of Fleurus. While Frederick's Extract of the work of Folard removed most of the original work's discussion of Polybius, over half of its pages were dedicated to a description of the 1705 battle of Cassano in the War of the Spanish Succession, and Frederick's introduction to the work specifically praised Turenne. Frederick's neglect of classical tactics thus reflected his fundamental focus on "the age of Louis XIV", and his desire to associate his own military achievements with those of the most famous French generals. ${ }^{57}$

\footnotetext{
${ }^{54}$ Johannes Kunisch, Der kleine Krieg. Studien zum Heerwesen des Absolutismus (Wiesbaden, 1973), 48.

${ }_{55}^{50}$ Guichard, Mémoires critiques et historiques, Vol. I, xxvi.

${ }^{56}$ Friedrich Moritz von Rohr, Des Herrn Grafen Turpin von Crisse, Brigadiers unter der französischen Armee und Mestre du Camp über ein Husaren Regiment, Versuche über die Kriegskunst, 2 vols. (Potsdam, 1756), Vol. I, xiii.

${ }^{57}$ Adam L. Storring, “"The Age of Louis XIV': Frederick the Great and French Ways of War", German History 38 (2020): 24-46.
} 
Whilst Frederick's contemporaries genuinely celebrated the achievements of their own age, particularly in natural philosophy, the claims of "moderns" could also be self-serving, and the Prussian king was no exception. ${ }^{58}$ The Dutch military reforms had centred on the re-introduction of ancient military drill, and it was therefore absurd for Frederick to argue in his Extract of the work of Folard that the ancient world had produced no classic works on war, only to praise the Dutch reforms (which had been based on classical works) a few lines later. ${ }^{59}$ Reflecting the position of many contemporary intellectuals, Frederick in his non-military writings had praise both for the ancients and the moderns. ${ }^{60}$ In the later 1740 s and the 1750 s, however, Frederick sought to establish his oblique order of battle as a new tactical system superseding all previous ones, and in this context it was natural that Frederick should strongly associate himself with the military "moderns". ${ }^{61}$ One enraptured contemporary declared that, "this [oblique] order is the most scientific, the most artful, the most perfect of all ... The Prussian tactics form an era in military history." ${ }^{, 62}$ Guichard similarly argued in his flattering 1774 Critical and Historical Memoirs on Several Points of Military Antiquities (which were dedicated to Frederick) that:

The Romans . . carried the art of war to the highest degree of perfection. But you, Sire, you have created a new tactic and through a great number of victorious battles you have at the same time furnished the most brilliant proof of its value. ${ }^{63}$

Frederick's Extract of the work of Folard specifically excluded the section in which the French thinker had set out his famous tactical system of column formations, and

\footnotetext{
${ }^{58}$ On this phenomenon more generally, see DeJean, Ancients against Moderns, 15-16.

${ }^{59}$ For contemporary works noting this, see Karl Theophil Guichard, Mémoires militaires sur les Grecs et les Romains, 2 vols. (The Hague, 1758), Vol. I, ix; Montecuccoli, Mémoires, 21. ${ }^{60}$ Euvres, Vol. VII, 65-6; Euvres, Vol. IX, 41-2, 244, 256; Euvres, Vol. XIV, 353; Euvres, Vol. XV, 157; Euvres, Vol. XXI, 3, 269-70; Euvres, Vol. XXII, 130; Euvres, Vol. XXIV, 326-7, 475-6. For other contemporary intellectuals, see Edelstein, The Enlightenment, 39-43, 49, 51-7, 69, 76-7, 107; Norman, Shock of the Ancient, 15-16, 21-3, 40-1, 46-9.

${ }^{61}$ Jürgen Luh, "Military Action and Military Reflection: Some Thoughts on Frederick's 'Eléments de Castramétrie et de Tactique' of 1770", Friedrich300 - Studien und Vorträge: Studien und Vorträge zur preußischen Geschichte des 18. Jahrhunderts der Stiftung Preußische Schlösser und Gärten (http://www.perspectivia.net/publikationen/friedrich300studien/luh_action, last accessed 18 June 2021), paragraph 7; Andreas Pečar, Autorität durch Autorschaft? Friedrich II. als Militärschriftsteller (Halle an der Saale, 2013), 19-20.

${ }^{62}$ Starkey, War in the Age of Enlightenment, 47-8.

${ }^{63}$ Guichard, Mémoires critiques et historiques, Vol. I, Unpaginated dedication.
} 
Frederick's introduction to the work argued that it was not necessary to consider the military science of earlier ages either. By implication, although Prussian officers were encouraged to adopt the offensive spirit of Folard and the French army, they should primarily follow the tactical system developed by, as Guichard put it, "this great king [Frederick], whose superior genius has given to the modern art of war that degree of consistency and perfection that it lacked, and which prevails in all respects over the practice of the ancients". ${ }^{64}$

\section{A "Military Revolution"}

Alongside the political culture of ordered states and the new intellectual culture of "our age," however, Frederick and his contemporaries also defined their own age in warfare in terms of changing technology and the tactics this fostered, although the precise timing of the decisive technological change was highly uncertain, just as contemporary intellectuals were vague about precisely when "our age" had begun. ${ }^{65}$ The British colonel Campbell Dalrymple declared in 1761 that a "military revolution" had been inaugurated by the invention of gunpowder, and this was an argument made by commentators as far back as the $16^{\text {th }}$ century. ${ }^{66}$

Other military thinkers, however, stressed more recent technological change, particularly the introduction of the flintlock musket and socket bayonet at the turn of the $17^{\text {th }}$ to the $18^{\text {th }}$ century, which increased the musket's rate of fire while making it no longer necessary to protect musketeers with separate units of pikemen. Instead, infantry was deployed in long lines to maximise firepower. ${ }^{67}$ Rohr portrayed change as evolutionary, noting "the gradually occurring alteration in weapons": "before the firearm appeared, one deployed the troops much deeper, ... In the days when pikes were used, one deployed a battalion differently than after their abolition. Before this

\footnotetext{
${ }^{64}$ Guichard, Mémoires critiques et historiques, Vol. IV, 3; Storring, "The Age of Louis XIV": 38-9. See also Guichard, Mémoires critiques et historiques, Vol. I, xli-xliii; Guichard, Mémoires critiques et historiques, Vol. IV, 25.

${ }^{65}$ Edelstein, The Enlightenment, 27.

${ }^{66}$ Neill, "Ancestral Voices": 518-9; Parker, The Military Revolution, 6, 18, 160, 238-9. See also Starkey, War in the Age of Enlightenment, 35.

${ }^{67}$ On the shift in warfare brought about by the flintlock musket and socket bayonet, see Black, A Military Revolution?, 93; Childs, Armies and Warfare in Europe, 106-8, 122; Strachan, European Armies, 16, 23.
} 
infantry and cavalry were deployed [mixed] among each other" and "fire worked differently". ${ }^{68}$ Both Rohr and Puységur discussed the tactics of the imperial field marshal Raimondo Montecuccoli (1609-80), arguing that changes in weapons technology made Montecuccoli's battle formations - based on cumbersome matchlock muskets and large numbers of pikemen - no longer appropriate. ${ }^{69}$ Writing in the 1720s, Quincy - another of Frederick's favourite authors - noted that Montecuccoli and Turenne had intermingled infantry, cavalry and artillery in their order of battle, but that, "since all of Europe currently observes the usage of putting the infantry in the centre and the cavalry on the flanks, one is obliged to conform to it". ${ }^{70}$ In this case, substantial change had occurred within a single generation.

The vast majority of the military authors read by Frederick, however, did not see this technological change as invalidating the relevance of classical military history. Feuquières and Quincy, firmly wedded to "the age of Louis XIV", eschewed classical examples, but Folard famously made a specific study of Polybius, and frequently referred to ancient examples. ${ }^{71}$ Montecuccoli recognized a substantial difference in arms between his own time and the classical world - dating the change to "the invention of powder" - but argued that one could still draw tactical lessons from the ancients. ${ }^{72}$ Prior to entering Frederick's service, Guichard said the same in his 1758 Military Memoirs on the Greeks and Romans. ${ }^{73}$ Maurice de Saxe proposed to equip contemporary troops with ancient weapons, and discussed the use of ancient tactics in his own day. ${ }^{74}$ Santa Cruz specifically stated his opposition to "the ridiculous opinion . . . that ancient histories are of very little use for the war of today",

\footnotetext{
${ }^{68}$ Rohr, Versuche über die Kriegskunst, Vol. I, x.

${ }^{69}$ Puységur, Art de la guerre, Vol. I, 36; Rohr, Versuche über die Kriegskunst, Vol. II, xvi.

${ }^{70}$ Charles Sevin, marquis de Quincy, Histoire militaire du règne de Louis le Grand, roy de France, 7 vols. (Paris, 1726), Vol. VII_II, 56. On Frederick's fondness for Quincy, see Hannelore Röhm and Sabine Scheidler, "Die Bibliotheken Friedrichs des Grossen", in Friederisiko - Friedrich der Grosse. Die Ausstellung, ed. Generaldirektion der Stiftung Preußische Schlösser und Gärten Berlin Brandenburg (Munich, 2012), 324, 327.

${ }^{71}$ Extrait tiré des Commentaires du chevalier Folard, 6-9, 11-13, 119-21; Quimby, Background of Napoleonic Warfare, 27; Quincy, Histoire militaire, Vol. VII_II. For a rare reference to classical history in Feuquières's work, see Feuquières, Mémoires, 30-1.

${ }^{72}$ Montecuccoli, Mémoires, 10-13, 24-5, 27-8, 191-2 (quotation, 11).

${ }^{73}$ Guichard, Mémoires militaires, Vol. I, 1.

${ }^{74}$ Maurice de Saxe, Les Rêveries, ou Mémoires sur l'art de la guerre, ed. Zacharie de Pazzi de Bonneville (The Hague, 1756), 29, 42-4, 82, 187-94.
} 
and illustrated his work using examples from the Bible and Greek and Roman history just as much as from wars of the gunpowder age and of his own day. ${ }^{75}$

The rhetorical nature of some of these claims is highlighted, however, by the example of Puységur. On one hand, the French author presented ancient authorities to legitimate his own ideas and loudly claimed that ancient warfare remained relevant despite differences in technology. On the other hand, as we have seen, he claimed a few pages later that his work superseded that of Montecuccoli because changes in technology had made the latter's ideas out-dated. ${ }^{76}$ Frederick's own claims of a technological revolution in military affairs were similarly made for rhetorical purposes, as part of an attempt to restore his authority at a period of particular crisis.

The most important technological change that Frederick confronted during his lifetime was the huge growth in the power of artillery in the mid $18^{\text {th }}$ century, as advances in gun-founding made cannon barrels stronger, enabling both a higher rate of fire and the casting of lighter and thus more mobile guns, while the introduction of the elevating screw allowed cannon to be laid more quickly and accurately. ${ }^{77}$ Frederick began the Seven Years War with a tactical system that was, as he put it, "founded on ... the necessity of attack" ${ }^{78}$ The greater power of artillery, however, combined with his enemies' well-chosen defensive positions, took a terrible toll on the Prussian army as it took the offensive at battles like Prague and Kolin in 1757 and Kay and Kunersdorf in 1759, trying with mixed success to apply Frederick's tactical system of the oblique order. ${ }^{79}$ In response to his setbacks, Frederick in the winters of 1758 and 1759 wrote military treatises that were intended to serve as apologies to his generals for his rashness and as promises that he would in future respect the destructive power of firearms. ${ }^{80}$

In these texts, Frederick claimed that there had been a fundamental change in warfare, but he did not consistently locate it at any one point in time or any one precise technology. Frederick's claims were thus a rhetorical device, not a precise

\footnotetext{
${ }^{75}$ Santa Cruz, Réflexions militaires, Vol. I, 28, 206-9, 214, 218-24; Santa Cruz, Réflexions militaires, Vol. III, 278-81, 293.

${ }^{76}$ Puységur, Art de la guerre, Vol. I, 3, 36-8; Puységur, Art de la guerre, Vol. II, 196-7.

${ }^{77}$ B. P. Hughes, Firepower: Weapons Effectiveness on the Battlefield, 1630-1850 (London, 1974), 94; Parker, The Military Revolution, 151.

${ }^{78}$ Euvres, Vol. XXVIII, 100.

${ }^{79}$ Dennis E. Showalter, The Wars of Frederick the Great (London and New York, 1996), 152-65, 240-50. On the heavy casualties in Frederick's battles, see Christopher Duffy, Frederick the Great: A Military Life (London, 1985), 66.

${ }^{80}$ Pečar, Autorität durch Autorschaft?, 22-31.
} 
historical analysis, but they were clearly a device that Frederick expected his generals to recognize and find convincing. In his Reflections on Certain Changes in the Way of Making War, finished on 27 December 1758, Frederick noted the effectiveness of Austrian defensive tactics in recent campaigns but argued that it was still possible to attack and defeat them. In this text, Frederick located change in the very recent past, recognizing that there had been considerable advances in firepower since the days of Feuquières, his favourite military author, whose aggressive strategic ideas reflected French practice from the early years of Louis XIV. ${ }^{81}$ In contrast, Frederick's Reflections on the Character and Military Talents of Charles XII, King of Sweden were written in October and November 1759, after the terrible defeats at Kay and Kunersdorf, and in this text Frederick used criticism of Charles XII, whom he compared with himself, as a proxy for admitting his own mistakes. ${ }^{82}$ The Swedish king, however, who reigned from 1697 to 1718 , belonged to the generation before the advent of the powerful new artillery. As a result, in order to argue that Charles (or rather Frederick himself) had failed to recognize the new developments in firepower, Frederick was obliged to date the change in warfare all the way back to "the invention of powder". ${ }^{83}$ In his two texts, Frederick thus provided no clear story of military change, but instead used the idea of a revolutionary change in warfare as a means indirectly to acknowledge his own mistakes.

Reflecting his master's new approach, Guichard in 1774 emphasized "the prodigious effect of . . . firearms," which now "prevailed" over "shock and the bladed weapon" ["l'arme blanche"]. ${ }^{84}$ Having in 1758 emphasized the continued relevance of classical tactics, Guichard in 1774 argued that technological change at the turn of the $18^{\text {th }}$ century had made them outmoded, as the long thin lines of infantry inaugurated

\footnotetext{
${ }^{81}$ Euvres, Vol. XXVIII, 167-83; Storring, "The Age of Louis XIV": 39-45.

${ }^{82}$ Eberhard Kessel, "Einleitung", in Friedrich der Große, Betrachtungen über die militärischen Talente und den Charakter Karls XII. Königs von Schweden (Berlin, 1936), 7 11; Andreas Pečar, "Friedrich der Große als Autor: Plädoyer für eine adressatenorientierte Lektüre seiner Schriften", in Friedrich der Große - eine perspektivische Bestandsaufnahme. Beiträge des ersten Colloquiums in der Reihe ,Friedrich300“vom 28./29. September 2007, eds. Michael Kaiser and Jürgen Luh (http://www.perspectivia.net/content/publikationen/friedrich300-colloquien/friedrichbestandsaufnahme/pecar_autor, last accessed 19 June 2021), paragraphs 40-46; Richard Nürnberger, "Friedrichs des Grossen Réflexions sur Charles XII", in Spiegel der Geschichte. Festgabe für Max Braubach zum 10. April 1964, eds. Konrad Repgen and Stephan Skalweit (Münster, 1964), 590-3.

${ }^{83}$ Euvres, Vol. VII, 83-4 (quotation, 83).

${ }^{84}$ Guichard, Mémoires critiques et historiques, Vol. I, xxvii-xxviii.
} 
by the flintlock musket and socket bayonet did "not at all resemble the tactic that Aelian, Arrian and Vegetius have shown to us". While Guichard was obliged to spend some time justifying why, in this case, there was still value in studying ancient military history, his new argument had the advantage of disproving the work of Folard - Guichard's main rival among $18^{\text {th }}$-century historians of ancient warfare - as Guichard now extolled the linear formations used by Frederick's Prussian army as superior to the deep columns favoured by Folard. ${ }^{85}$

In 1777, however, Frederick went back on his earlier claims, telling the Dowager Electress Maria Antonia of Saxony (1724-80) that, "although the invention or the discovery of powder totally changed the way of making war, there are nonetheless, in the tactics of the Greeks, things which merit our reflections and which may still serve as an example". Frederick's statement, ironically made as part of a letter that argued for the superiority of the moderns over the ancients, was a reminder that, although contemporaries genuinely felt that technological change had made their warfare different from previous ages, claims about the effects of technology on war might also be made simply for rhetorical purposes. ${ }^{86}$

\section{Pharsalus}

While Frederick thus normally situated his battle tactics within "our age" and particularly in "the age of Louis XIV", he made an exception when it came to his favourite ancient battle, Julius Caesar's decisive victory over Pompey at Pharsalus in 48 BC. In his introduction to Folard's work, Frederick maintained that the only lesson to be learned from Caesar's campaigns was the deployment of his cavalry at Pharsalus. ${ }^{87}$ In that campaign, seeking to offset his huge numerical disadvantage, with only 1,000 cavalry against Pompey's 7,000, Caesar interspersed foot-soldiers among his horsemen: a technique learnt from the Germanic tribes. This allowed them to win successes in skirmishes against the Pompeians. In the battle itself, Caesar deployed

\footnotetext{
${ }^{85}$ Guichard, Mémoires critiques et historiques, Vol. I, xxvi- xlix (quotation, xxviii); Guichard, Mémoires critiques et historiques, Vol. IV, 1-11. On Guichard's opposition to Folard, see Jean-Jacques Langendorf, “'Des diamants au milieu du fumier', Folard en Allemagne (1750-1800)", in Combattre, gouverner, écrire: études réunis en l'honneur de Jean Chagniot, ed. Economica (Paris, 2003), 478, 482-3.

${ }^{86}$ Euvres, Vol. XXIV, 322-8 (quotation, 327).

${ }^{87}$ Extrait tiré des Commentaires du chevalier Folard, 4.
} 
six detached cohorts of line infantry (perhaps 3,000 troops) behind his cavalry. When, despite being strengthened with foot soldiers, his horsemen were routed by the overwhelming numbers of their opponents, these six cohorts in turn attacked and routed the Pompeian cavalry, then fell on the left flank and rear of Pompey's infantry, playing the crucial role in achieving victory. ${ }^{88}$ Pharsalus thus offered an example of how infantry support could enable cavalry to overcome superior numbers of opponents.

Notably, Frederick himself interspersed infantry units among his cavalry at his first battle - at Mollwitz on 10 April 1741 - where, just like Caesar, he faced an Austrian army whose cavalry were much more numerous than his own. His battle plan specified that grenadier battalions should accompany both cavalry wings and that the cavalry should maintain the same pace as them while attacking. ${ }^{89}$ Indeed, he had written to Field Marshal Kurt Christoph von Schwerin the month before the battle, proposing that, since "the enemy relies very much on their cavalry, . . . our cavalry should have infantry interspersed among them in the order of battle". ${ }^{90}$ Frederick's innovation was disastrously unsuccessful, however, as the Austrian cavalry routed the stationary Prussian horsemen and swept the king along with them. ${ }^{91}$

Frederick claimed in the 1775 version of his History of My Times that his tactics at Mollwitz followed the example of King Gustavus Adolphus of Sweden (reigned 1611-32) at the battle of Lützen in $1632 .{ }^{92}$ The Theatri Europaei, a chronicle of European history that Frederick studied as a child, did indeed describe Gustavus

\footnotetext{
${ }^{88}$ Pierre Cagniart, "The Late Republican Army (146-30 BC)", in A Companion to the Roman Army, ed. Paul Erdkamp (Malden, MA, Oxford, Victoria, 2007), 88; Catherine M. Gilliver, "Battle", in The Cambridge History of Greek and Roman Warfare Volume II: Rome from the Late Republic to the Late Empire, eds. Philip Sabin, Hans van Wees, Michael Whitby (Cambridge, 2007), 135; Lawrence Keppie, "The Roman Army of the Later Republic", in Warfare in the Ancient World, ed. John Hackett (London, 1989), 188. For works read by Frederick, see Gaius Julius Caesar, Les Commentaires, trans. Perrot d'Ablancourt, $3^{\text {rd }}$ edn. (Paris, 1658), 440, 447, 450-3; Jean-Baptiste-Louis Crevier and Charles Rollin, Histoire romaine depuis la fondation de Rome jusqu'à la bataille d'Actium, 16 vols. (Paris, 1738-48) Vol. XIV, 13-17, 21-3; Lucan, La Pharsale, trans. Georges de Brébeuf (Paris, 1670), 255-7; Plutarch, Les vies des hommes illustres, trans. André Dacier, 10 vols. (Amsterdam, 1735), 469-70, 475-7.

${ }^{89}$ Großer Generalstab Kriegsgeschichtliche Abteilung II, Die Kriege Friedrichs des Großen. Erster Theil: Der Erste Schlesischer Krieg, 1740-1742, 3 vols. (Berlin, 1890-3), Vol. I, 3912, 400-2, 419, 460-1, 124*-125*, 128*.

${ }^{90}$ Geheimes Staatsarchiv Preußischer Kulturbesitz, I.HA Rep.96 Nr.84 Q2: Field Marshal Schwerin to Frederick II, 26.3.1741. I am grateful to Jasper Heinzen for his help with the translation of this passage. Any errors are mine alone.

${ }^{91}$ Großer Generalstab, Erste Schlesischer Krieg, Vol. I, 399-404, 419, 456-7.

${ }^{92}$ Euvres, Vol. II, 81.
} 
interspersing musketeers among his cavalry both at the battle of Breitenfeld in 1631 and at Lützen, but the tactic did not have a decisive impact on the result of either battle. ${ }^{93}$ Certainly, Frederick's literary associates flatteringly compared him with Gustavus Adolphus, and indeed Frederick's History of Brandenburg portrayed the Swedish king as a great man very much like the Prussian one: an exponent of military strength, unscrupulous and seeking personal glory, but in the process liberating Germany from Habsburg domination. ${ }^{94}$ Frederick's history, however, did not describe Gustavus's battle tactics at all. For Breitenfeld, Frederick merely said that "Gustavus Adolphus ... falls upon the imperials, whom he defeats totally". ${ }^{95} \mathrm{He}$ did not describe Gustavus's later campaigns in southern Germany, and on Lützen he said only, "the King of Sweden . . . arrives, he wins the famous battle of Lützen, and loses his life fighting". ${ }^{96}$ Moreover, the name of Gustavus appears only once in the three published volumes of Frederick's military writings, in a treatise written in 1781 near the end of his life. Even then Frederick did not go into details, merely listing the Swedish king's campaigns among other historical examples from which his officers could learn. ${ }^{97}$ This was in total contrast to the king's repeated and detailed descriptions of battles from the wars of Louis XIV. In this context, the Prussian king's 1775 claim to have followed Gustavus's tactics, something he had not mentioned in the original 1746 version of his memoirs, seems like a belated attempt to excuse his youthful mistake by invoking the example of the great Swedish general. ${ }^{98}$ While Frederick undoubtedly compared himself to Gustavus on the political level, the Swedish king's influence on Frederick's battle tactics must remain unproven.

In contrast, Frederick's writings described in detail Caesar's campaign against Pompey in Greece in $48 \mathrm{BC}$ and also showed a good understanding of the siege of

\footnotetext{
${ }^{93}$ Johann Philipp Abelinus, Theatri Europaei. Das ist, Historischer Chronick, oder wahrhaffter Beschreibung aller fürnehmen und denckwürdigen Geschichten, so sich hin und wieder in der Welt, meistentheils aber in Europa, von Anno Christi 1629 biß auff das Jahr 1633. zugetragen. Der Ander Theil (Frankfurt am Main, 1679), 432-5, 748-50. On Frederick studying the Theatrum Europaeum, see Ernst Bratuscheck, Die Erziehung Friedrichs des Großen (Berlin, 1885), 26-7.

${ }^{94}$ Euvres, Vol. I, 41-53, 239; CEuvres, Vol. IX, 167; Euvres, Vol. X, 284-5; Euvres, Vol. XVIII, 123; Euvres, Vol. XXII, 111-2; Euvres, Vol. XXIII, 393; Euvres, Vol. XXIV, 434; Euvres, Vol. XXV, 111-2.

${ }^{95}$ Euvres, Vol. I, 49.

${ }^{96}$ Euvres, Vol. I, 50-1 (quotation, 51).

${ }^{97}$ Euvres, Vol. XXX, 399.

${ }^{98}$ Max Posner, ed., "Frédéric II. Histoire de Mon Temps (Redaktion von 1746)", Publicationen aus den K. preussischen Staatsarchiven 4 (1879): 226.
} 
Marseille in 49 BC, reflecting Frederick's particular interest in Caesar's

Commentaries. ${ }^{99}$ It is well known that Frederick was inspired by Caesar, saw his invasion of the Austrian province of Silesia in 1740 as comparable with Caesar's destruction of the Roman Republic, and was particularly fascinated by the battle of Pharsalus. ${ }^{100}$ When Frederick in 1740 presented himself to French statesmen as another Gustavus Adolphus, ready to fight for French interests in Germany, this was a political move to present himself as a potential French ally, not a genuine reflection of Frederick's feelings. ${ }^{101}$ In contrast, Frederick's private letters to close associates such as Francesco Algarotti and Charles-Étienne Jordan were full of excited comparisons of himself with Caesar, both during the planning of the invasion of Silesia and its execution. ${ }^{102} \mathrm{He}$ famously told his foreign minister Heinrich von Podewils that he was "cross[ing] the Rubicon" when he invaded the province, and he celebrated his victory in the First Silesian War (1740-2) with a performance of Carl Heinrich Graun's opera Caesar and Cleopatra. ${ }^{103}$ To flatter his monarchical patron, Algarotti compared Frederick repeatedly to Caesar during the First Silesian War, declaring in February 1742 that, "Your Majesty is going to make perhaps the most important march that has been made since Pharsalus and Philippi [site of the defeat of Caesar's assassins Brutus and Cassius in $42 \mathrm{BC}]$ ". ${ }^{104}$ Voltaire flatteringly compared both Mollwitz and the conquest of Silesia to Caesar's achievement at Pharsalus, while Frederick himself grandiloquently declared that, "since the war of Pharsalus, there were never greater interests discussed than in the present war". ${ }^{105}$ While it is impossible to prove beyond doubt exactly what inspired Frederick to intersperse grenadiers among his cavalry, it seems highly likely that he hoped to make Mollwitz his own personal battle of

\footnotetext{
${ }^{99}$ For battles of the Roman Civil War, see Euvres, Vol. X, 276-7, 290. For Frederick reading Caesar's Commentaries, see Euvres, Vol. I, xlviii; Euvres, Vol. II, xvii; Euvres, Vol. VII, 119; Euvres, Vol. XVII, 175; Euvres, Vol. XIX, 403-4; Euvres, Vol. XX, 29-30; Politische Correspondenz, Vol. V, 234.

${ }^{100}$ Luh, Der Große, 12-13, 53; Ullrich Sachse, Cäsar in Sanssouci. Die Politik Friedrichs des Großen und die Antike (Munich, 2008), 191-6; Schieder, Friedrich der Große, 356; Gregor Vogt-Spira, "Das antike Rom im geistigen Haushalt eines Königs", in Friedrich der Große in Europa, eds. Sösemann and Vogt-Spira, Vol. I, 137-9.

${ }^{101}$ Politische Correspondenz, Vol. I, 4, 43. See also Euvres, Vol. XV, 86.

${ }^{102}$ Euvres, Vol. XVII, 92; Euvres, Vol. XVIII, 22, 24.

${ }^{103}$ Tim Blanning, Frederick the Great King of Prussia (London, 2015), 139-40; Politische Correspondenz, Vol. I, 147.

${ }^{104}$ CEuvres, Vol. XVIII, 33-6, 41 (quotation, 35).

${ }^{105}$ Euvres, Vol. XXII, 77, 130, 146 (quotation, 130).
} 
Pharsalus, where he would offset the superior Austrian cavalry by interspersing infantry among his horsemen.

While Frederick after Mollwitz never again interspersed foot-soldiers among his cavalry, the years of peace between the Second Silesian War (1744-5) and the Seven Years War saw the Prussian king still attempt to emulate Caesar's tactic of using a detached infantry force on his flank to defeat enemy cavalry and then outflank their infantry. Twice in his 1748 General Principles, and again once in his 1755 Thoughts and General Rules, Frederick sketched out battle plans in which the cavalry on the Prussian flanks would be supported by infantry, which might aid it in defeating the enemy cavalry and, once these had fled, would fall on the flank of the enemy infantry while the rest of the Prussian army attacked them in front. ${ }^{106}$ In one case, Frederick specifically described this as an example of his trademark "oblique order of battle", and indeed he proposed to win with his right flank, just as Caesar had done at Pharsalus. ${ }^{107}$ In another scenario, Frederick proposed also to distribute dragoons among the second line of infantry, seeking to recreate his own success at the battle of Hohenfriedberg (4 June 1745), where the Bayreuth Dragoon Regiment had routed the Austrians by exploiting a gap in their infantry line. ${ }^{108}$ Thus, although Frederick did not actually employ such tactics in the Seven Years War, his writings repeatedly set out plans for emulating Caesar's victory at Pharsalus, and sought to combine it with the emulation of Frederick's own greatest victory to date.

\section{6. "The Conqueror"}

Frederick's desire to emulate Caesar reflected his broader use of classical history as inspiration for the bold strategies he favoured. While the Prussian king generally stayed tactically rooted in the "age of Louis XIV", he found numerous examples from classical history to inspire his strategic ideas. In contrast to his almost total silence on the battle tactics of the Second Punic War, Frederick loved to describe again and again the bold strategy of Scipio Africanus in 204-202 BC, who, "From the Tiber desolated by the demon of war / Carries to the regions of the guilty land / Carnage and

\footnotetext{
${ }^{106}$ Euvres, Vol. XXVIII, 83-4, 88-90, 127-8.

${ }^{107}$ Euvres, Vol. XXVIII, 83.

${ }^{108}$ Euvres, Vol. XXVIII, 88-90.
} 
horror", and to tell "by what blow Scipio saved Rome in Africa / Attracting Hannibal to frightened Carthage". ${ }^{109}$ He similarly praised the boldness of Hannibal in crossing the Alps in $218 \mathrm{BC}$ to carry the war into Italy. ${ }^{110}$ Whereas Frederick made no mention of Hannibal's tactics of envelopment at the famous battle of Cannae in $216 \mathrm{BC}$, he repeatedly discussed the strategic implications of the battle, praising the determination of the Romans in continuing the war despite their defeats, and criticising Hannibal's failure to exploit his victory by capturing Rome. ${ }^{111}$

Frederick's interest in classical warfare at the strategic level reflected an idealised conception of an ancient world freed from the limitations of his own age. In his Thoughts and General Rules, Frederick lamented that "as, in all our wars, Europe is divided into two great factions, a certain balance of forces results, which means that, after many successes, one has scarcely advanced when the general peace is made". ${ }^{112}$ In contrast, Frederick and Electress Maria Antonia of Saxony in 1777 sketched out an image of the ancient world as much simpler. "I see many great men doing impressive things there", commented the electress, "but in a very narrow circle, having only few obstacles to overcome, not knowing the multiplicity or the complication of our modern interests". ${ }^{113}$ Frederick agreed: "[contemporary] European politics is infinitely more complicated than that of the Greeks; the machine is more vast and the springs more complicated". He argued that this reflected the alliance systems that had developed "since the age of [Holy Roman Emperor] Charles $\mathrm{V}$ [reigned 1519-56]", and the appearance since then of "prodigious armies". 114

Frederick and many of his contemporaries argued that expansive conquests had been much easier for those who were not limited by the conditions of contemporary warfare. This included not just figures from the ancient world but also generals such as Charles XII who campaigned outside of "policed land[s]". In his Refutation of Machiavelli, Frederick argued that:

\footnotetext{
${ }^{109}$ Euvres, Vol. VII, 84-5; Euvres, Vol. VIII, 169, 319; Euvres, Vol. IX, 85, 167, 262; Euvres, Vol. X, 283-4 (quotation, 283); Euvres, Vol. XII, 2-3 (quotation, 3); Euvres, Vol. XIII, 152-3, 160; Euvres, Vol. XIX, 59.

${ }^{110}$ Euvres, Vol. VIII, 169, 319; Euvres, Vol. IX, 262; Euvres, Vol. X, 304-5.

${ }^{111}$ Euvres, Vol. III, 41; Euvres, Vol. IX, 155; Euvres, Vol. X, 40; Euvres, Vol. XI, 61;

Euvres, Vol. XII, 2; Euvres, Vol. XVIII, 135; Politische Correspondenz, Vol. XX, 509. On Cannae, see Connolly, Greece and Rome at War, 184-8.

${ }^{112}$ Euvres, Vol. XXVIII, 139.

${ }^{113}$ Euvres, Vol. XXIV, 325.

${ }^{114}$ Euvres, Vol. XXIV, 328.
} 
Alexander, Caesar, Charles XII owed their glory to the fact that they found few fortresses in the countries they conquered . . Eugene, Villars, Marlborough, Luxembourg were quite different captains from Charles and Alexander, but fortresses in a certain way blunted the brilliance of their successes, which, when one judges them soundly, are preferable to those of Alexander and Charles. ${ }^{115}$

Military commentators had made similar arguments about the impact of fortresses since the $16^{\text {th }}$ century. ${ }^{116}$ The great French engineer Sébastien Le Prestre de Vauban (1633-1707) - whose work was published in 1739-42 and dedicated to Frederick - for instance noted that, because of the numerous fortresses there, "a battle in the Low Countries usually has few consequences" and "one has often seen conquerors halted in the middle of their course".

It took much less time and effort to render oneself master of all of Asia than it took to conquer only part of the Low Countries . . In these vast countries where there are none or very few fortified places, the victorious pursue the defeated army until it is entirely dispersed. This is normally followed by the sack of the provinces which find themselves thereby forced to accept the law of the conqueror. This is precisely what Alexander did, rendering himself master of the redoubtable monarchy of the Persians by means of three battles, and one sees the same thing with Caesar . . or Tamerlane, the famous conqueror of Asia. ${ }^{117}$

Santa Cruz, who scarcely distinguished between different periods of history, maintained that Gustavus Adolphus still considered it possible to emulate "ancient conquerors", despite the advent of firearms and the new fortresses. ${ }^{118}$ However, he also described Prince Eugene of Savoy (1663-1736) complaining that Alexander would never have made such great conquests if he had had to get permission from the

\footnotetext{
${ }^{115}$ Euvres, Vol. VIII, 150, 297.

${ }^{116}$ Parker, The Military Revolution, 6, 16.

${ }^{117}$ Sébastien le Prestre de Vauban, De l'attaque et de la défense des places, 2 vols. (The Hague, 1737-42), Vol. II, 'Preface' (unpaginated original dedication). See also Vauban, De l'attaque et de la défense des places, Vol. I, *2 recto - *3 verso.

${ }^{118}$ Santa Cruz, Réflexions militaires, Vol. I, 27-8 (quotation, 27).
} 
Dutch deputies before undertaking anything. ${ }^{119}$ Thus, even Santa Cruz to an extent followed romanticised ideas that, in the ancient world, and in other lands outside of contemporary western Europe, it had been much easier to conquer large areas through decisive battles. ${ }^{120}$

Ideas of imitating ancient conquerors shaped Frederick's strategy from his earliest days. Frederick's 1731 letter to his chamberlain Dubislav Gneomar von Natzmer setting out future targets for Prussian expansion was a naive document, written only at the beginning of Frederick's period of intensive reading during the 1730s. ${ }^{121}$ Frederick, however, already imagined how "I advance always from country to country, from conquest to conquest, proposing for myself, like Alexander, always new worlds to conquer". ${ }^{122}$ Whereas, as noted above, Frederick never discussed Alexander's battle tactics in his writings, the Macedonian king was already well established in Frederick's mind as an example of a conqueror of vast territories.

Frederick's attempt to emulate classical conquerors was seen most strikingly at the beginning of the Seven Years War. Writing to Algarotti in December 1756 and referring to the limited campaign by which he had occupied Saxony that year at the start of the war, Frederick said:

Everything we have done this year [in Saxony] is only a weak prelude to what you will learn next year. We started a little too late to be able to undertake a lot. But, whatever we do, ... we are not living in the age of the Caesars. All that one can do at present is, I believe, to reach the highest point of mediocrity. The limits of the age do not extend further . . P.S. The trifles that have happened this year are just a prelude to the next, and we have not done anything yet if we do not imitate Caesar on the day of Pharsalus. ${ }^{123}$

Writing to his sister Anna Amalia in March 1757, just before the opening of the new campaign, Frederick was even more explicit:

\footnotetext{
${ }^{119}$ Santa Cruz, Réflexions militaires, Vol. I, 253.

${ }^{120}$ On the reality of ancient warfare, see Cathal J. Nolan, The Allure of Battle: A History of How Wars Have Been Won and Lost, paperback edn. (New York, 2019), 20-26.

${ }^{121}$ Berney, Friedrich der Grosse, 32-3; Luh, Der Große, 46.

${ }^{122}$ Euvres, Vol. XVI, 4.

${ }^{123}$ Euvres, Vol. XVIII, 116-7.
} 
This next campaign is like that of Pharsalus for the Romans, or that of Leuctra for the Greeks, or that of Denain [in 1712] for the French, or like the siege of Vienna [in 1683] for the Austrians. These are the epochs that decide everything, and which change the face of Europe. ${ }^{124}$

When a major battle was fought at Prague on 6 May 1757, both Frederick and (in flattering response) Algarotti compared it to Pharsalus. Frederick concluded his detailed description of the battle by claiming that, "the king will find himself . . , in less than a month, having conquered a kingdom [Bohemia]". ${ }^{125}$ In Frederick's strategic thinking, therefore, Pharsalus was an example of a decisive battle leading to the conquest of "a kingdom": an achievement of the kind that was possible in previous ages but scarcely possible in his own.

\section{Conclusion}

King Frederick II's account of military history reveals the sharp distinctions that he and his contemporaries made between their own time and previous ages. On one hand, stronger government now imposed order to prevent destructive religious and civil wars. On the other hand, intellectual developments (most notably the "new philosophy", the so-called "Scientific Revolution") were seen as making "our age" more advanced than any that had come before. Frederick's portrayal of military history is a reminder that the narrative of intellectual progress existed alongside a narrative of states bringing order, and that monarchs like Louis XIV of France and Frederick II of Prussia presented themselves as exemplifying both developments. Not only did the Prussian army epitomise the disciplined soldiers expected of "policed nations", but Frederick situated his battle tactics - particularly his trademark "oblique order of battle" - firmly in "our age", and particularly in "the age of Louis XIV".

The classical world was an important inspiration for attempts to impose order, particularly in the military sphere, but intellectually the distinction between "our age" and previous ages made the ancient past into a deeply foreign world. This foreignness, however, also made ancient history an attractive alternative to the constraints of the

\footnotetext{
${ }^{124}$ Euvres, Vol. XXVII I, 438.

${ }^{125}$ CEuvres, Vol. XVIII, 119-22 (quotation, 121-2).
} 
present day and, at the strategic level, Frederick turned to an idealised classical world in order to envisage conquests that went beyond what was possible within his own states system. He particularly admired Julius Caesar, and sought again and again to win his own personal battle of Pharsalus. Just as, in the later $18^{\text {th }}$ century, the philhellene Johann Joachim Winckelmann imagined an idealized and a-historic ancient Greece to support his democratic ideas, so the monarchical warlord Frederick earlier in the century yearned for an age where classical conquerors could occupy whole states through decisive battles, unfettered by the limits of the European balance of power.

The example of Frederick also shows that ideas of change in military affairs are driven not just by actual change (for instance in technology or state structures) but also by how soldiers and military writers perceive the relationship between the military methods of their own time and those of previous ages. Moreover, military figures may choose to manipulate such perceptions for their own purposes. ${ }^{126}$ Frederick does seem to have had a largely consistent view of military history, which substantially influenced his own military thought. Espousing the claims of "moderns" that "our age" was far superior to the ancients was, however, also a convenient means by which the Prussian king could portray his own tactical system as surpassing everything that had gone before. Similarly, while Frederick and the military authors he read did recognise genuine developments in military technology in early modern Europe, there was just as much dispute among contemporaries as there is among modern historians over the timing of this change and the degree to which it had made the methods of the classical world out of date. In such circumstances, ancient history could be readily appropriated or rejected to suit a given rhetorical purpose, and Frederick used ideas of fundamental changes in warfare primarily as a coded apology for his own mistakes as a general. The rhetoric of military change could be as important as the reality, and Frederick played on concepts of different ages of warfare in order to represent himself to best advantage.

\section{Bibliography}

\footnotetext{
${ }^{126}$ On this phenomenon, see Ken Alder, Engineering the Revolution: Arms and Enlightenment in France, 1763-1815 (Princeton, NJ, 1997), 346-51.
} 
Abelinus, Johann Philipp. Theatri Europaei. Das ist, Historischer Chronick, oder wahrhaffter Beschreibung aller fürnehmen und denckwürdigen Geschichten, so sich hin und wieder in der Welt, meistentheils aber in Europa, von Anno Christi 1629 biß auff das Jahr 1633. zugetragen. Der Ander Theil (Frankfurt am Main: Verlag Matthai Merian, Caspar Merian, und Thomas-Matthias Götzens, 1679).

Alder, Ken. Engineering the Revolution: Arms and Enlightenment in France, 17631815 (Princeton, NJ: Princeton University Press, 1997).

Berney, Arnold. Friedrich der Grosse. Entwicklungsgeschichte eines Staatsmannes (Tübingen: Verlag von J.C.B. Mohr (Paul Siebeck), 1934).

Biskup, Thomas. Friedrichs Größe. Inszenierung des Preußenkönigs in Fest und Zeremoniell 1740-1815 (Frankfurt am Main, New York: Campus Verlag, 2012).

Black, Jeremy. A Military Revolution? Military Change and European Society 15501800 (London: Macmillan, 1991).

Black, Jeremy. "Eighteenth-Century Warfare Reconsidered.” War in History 1 (1994), 215-32.

Blanning, Tim. Frederick the Great King of Prussia (London: Allen Lane, 2015).

Bratuscheck, Ernst. Die Erziehung Friedrichs des Großen (Berlin: Verlag von Georg Reimer, 1885).

Buckler, John. The Theban Hegemony, 371-362 B.C. (Cambridge, MA, and London: Harvard University Press, 1980).

Caesar, Gaius Julius. Les Commentaires, trans. Perrot d'Ablancourt, $3^{\text {rd }}$ edn. (Paris: Augustin Courbé, 1658). 
Cagniart, Pierre. "The Late Republican Army (146-30 BC)." In A Companion to the Roman Army, ed. Paul Erdkamp (Malden, MA, Oxford, Victoria: Blackwell Publishing, 2007), 80-95.

Childs, John. Armies and Warfare in Europe, 1648-1789 (Manchester: Manchester University Press, 1982).

Clark, Christopher. Time and Power: Visions of History in German Politics, from the Thirty Years' War to the Third Reich (Princeton, NJ, and Oxford: Princeton University Press, 2019).

Connolly, Peter. Greece and Rome at War (London: Macdonald \& Co., 1988).

Cramer, Friedrich, ed. Zur Geschichte Friedrich Wilhelms I. und Friedrichs II. Könige von Preußen, $3^{\text {rd }}$ edn. (Leipzig: Ludwig Schreck, 1835).

Crevier, Jean-Baptiste-Louis and Charles Rollin. Histoire romaine depuis la fondation de Rome jusqu'à la bataille d'Actium. 16 vols. (Paris: La Veuve Estienne \& Fils and Desaint \& Saillant, 1738-48).

Cunha, Alexandre Mendes. "A Previously Unnoticed Swiss Connection in the Dissemination of Cameralist Ideas during the Second Half of the Eighteenth Century." History of Political Economy 49 (2017), 497-529.

Dantal, C. Les Délassemens littéraires ou Heures de lecture de Frédèric II (Elbing: F.T. Hartmann, 1791).

DeJean, Joan. Ancients Against Moderns: Culture Wars and the Making of a Fin de Siècle (Chicago, IL, and London: The University of Chicago Press, 1997).

Duffy, Christopher. Frederick the Great: A Military Life (London: Routledge \& Kegan Paul, 1985). 
Duffy, Christopher. The Army of Frederick the Great, $2^{\text {nd }}$ edn. (Chicago, IL: The Emperor's Press, 1996).

Edelstein, Dan. The Enlightenment: A Genealogy (Chicago, IL, and London: The University of Chicago Press, 2010).

Extrait tiré des Commentaires du chevalier Folard sur l'Histoire de Polybe, pour l'usage d'un officier (Berlin, 1753).

Ferrier-Caverivière, Nicole. L'image de Louis XIV dans la littérature française de 1660 à 1715 (Paris: Presses Universitaires de France, 1981).

Feuquières, Antoine de Pas, marquis de. Mémoires, new edn. (London: Pierre Dunoyer, 1736).

Fink, Gonthier-Louis. "Die literarischen Beziehungen Friedrichs zu Frankreich.” In Panorama der fridericianischen Zeit. Friedrich der Grosse und seine Epoche. Ein Handbuch, ed. Jürgen Ziechmann (Bremen: Edition Ziechmann, 1985), 243-9.

Gat, Azar. The Origins of Military Thought from the Enlightenment to Clausewitz (Oxford: Oxford University Press, 1989).

Gay, Peter. Voltaire's Politics: The Poet as Realist (Princeton, NJ: Princeton University Press, 1959).

Gilliver, Catherine M. “Battle.” In The Cambridge History of Greek and Roman Warfare Volume II: Rome from the Late Republic to the Late Empire, eds. Philip Sabin, Hans van Wees, Michael Whitby (Cambridge: Cambridge University Press, 2007), 122-57.

Großer Generalstab Kriegsgeschichtliche Abteilung II. Die Kriege Friedrichs des Großen. Erster Theil: Der Erste Schlesischer Krieg, 1740-1742. 3 vols. (Berlin: Ernst Siegfried Mittler und Sohn, 1890-3). 
Großer Generalstab Kriegsgeschichtliche Abteilung II. Friedrich des Großen Anschauungen vom Kriege in ihrer Entwickelung von 1745 bis 1756 (Berlin: Ernst Siegfried Mittler und Sohn, 1899).

Guichard, Karl Theophil. Mémoires militaires sur les Grecs et les Romains. 2 vols. (The Hague: Pierre de Hondt, 1758).

Guichard, Karl Theophil. Mémoires critiques et historiques sur plusieurs points d'antiquités militaires. 4 vols. (Berlin: Haude et Spener, 1774).

Härter, Karl, ed. Policey und frühneuzeitliche Gesellschaft (Frankfurt am Main: Vittorio Klostermann, 2000).

Hughes, B. P. Firepower: Weapons Effectiveness on the Battlefield, 1630-1850 (London: Arms and Armour Press, 1974).

Jähns, Max. Geschichte der Kriegswissenschaften vornehmlich in Deutschland. 3 vols. (Munich and Leipzig: R. Oldenbourg, 1889-91).

Keppie, Lawrence. "The Roman Army of the Later Republic." In Warfare in the Ancient World, ed. John Hackett (London: Sidgwick and Jackson, 1989), 169-91.

Kessel, Eberhard. "Einleitung.” In Friedrich der Große, Betrachtungen über die militärischen Talente und den Charakter Karls XII. Königs von Schweden (Berlin: Junker und Dünnhaupt Verlag, 1936), 5-16.

Koselleck, Reinhart. Futures Past: On the Semantics of Historical Time, trans. Keith Tribe (Cambridge, MA, and London: The MIT Press, 1985).

Koser, Reinhold, ed. Briefwechsel Friedrichs des Großen mit Grumbkow und Maupertius (1731-1759) (Leipzig: Verlag von S. Hirzel, 1898).

Krieger, Bogdan. Frederick the Great and his Books (New York: Columbia University in the City of New York and the Germanistic Society of America, 1913). 
Krieger, Bogdan. Friedrich der Große und seine Bücher (Berlin and Leipzig: Verlag von Giesecke \& Debrient, 1914).

Kunisch, Johannes. Der kleine Krieg. Studien zum Heerwesen des Absolutismus (Wiesbaden: Steiner Verlag, 1973).

Langendorf, Jean-Jacques. “'Des diamants au milieu du fumier', Folard en Allemagne (1750-1800)." In Combattre, gouverner, écrire: études réunis en l'honneur de Jean Chagniot, ed. Economica (Paris: Economica; Institut de stratégie comparée; Commission française d'histoire militare, 2003), 475-85.

Liaropoulos, Andrew N. "Revolutions in Warfare: Theoretical Paradigms and Historical Evidence: The Napoleonic and First World War Revolutions in Military Affairs." The Journal of Military History 70 (2006), 363-84.

Lifschitz, Avi. “Introduction.” In Frederick the Great's Philosophical Writings, ed. Avi Lifschitz, trans. Angela Scholar (Princeton, NJ, and Oxford: Princeton University Press, 2021), vii-xlii.

Lifschitz, Avi. "Philosophy and Political Agency in the Writings of Frederick II of Prussia." The Historical Journal 64 (2021), 533-56.

Lucan, La Pharsale, trans. Georges de Brébeuf (Paris: Jean Ribou, 1670).

Luh, Jürgen. Kriegskunst in Europa 1650-1800 (Cologne, Weimar, Vienna: Böhlau Verlag, 2004).

Luh, Jürgen. Der Große. Friedrich II. von Preussen (Munich: Siedler Verlag, 2011).

Luh, Jürgen. "Military Action and Military Reflection: Some Thoughts on Frederick's 'Eléments de Castramétrie et de Tactique' of 1770." Friedrich300 - Studien und Vorträge: Studien und Vorträge zur preußischen Geschichte des 18. Jahrhunderts der Stiftung Preußische Schlösser und Gärten 
(http://www.perspectivia.net/publikationen/friedrich300-studien/luh_action, last accessed 18 June 2021).

Marwitz, Ullrich. "Friedrich der Große als Feldherr." In Friedrich der Große und das Militärwesen seiner Zeit, ed. Militärgeschichtliches Forschungsamt (Herford, Bonn: Verlag E.S. Mittler und Sohn, 1987), 73-88.

Meinecke, Friedrich. Machiavellism: The Doctrine of Raison d'Etat and its Place in Modern History, trans. Douglas Scott (London: Routledge and Kegan Paul, 1957).

Montecuccoli, Raimondo. Mémoires, new edn. (Paris: Savoye, 1746).

Montesquieu, Charles-Louis de Secondat Baron de. Considérations sur les causes de la grandeur des Romains et de leur décadence, $2^{\text {nd }}$ edn. (Amsterdam: Jacques Desbordes, 1735).

Neill, Donald A. "Ancestral Voices: The Influence of the Ancients on the Military Thought of the Seventeenth and Eighteenth Centuries." The Journal of Military History 62 (1998), 487-520.

Nolan, Cathal J. The Allure of Battle: A History of How Wars Have Been Won and Lost, paperback edn. (New York: Oxford University Press, 2019).

Norman, Larry F. The Shock of the Ancient: Literature \& History in Early Modern France (Chicago, IL, and London: The University of Chicago Press, 2011).

Nürnberger, Richard. "Friedrichs des Grossen Réflexions sur Charles XII.” In Spiegel der Geschichte. Festgabe für Max Braubach zum 10. April 1964, eds. Konrad Repgen and Stephan Skalweit (Münster: Verlag Aschendorff, 1964), 590-601.

Oestreich, Gerhard. Neostoicism and the Early Modern State, eds. Brigitta Oestreich and H. G. Koenigsberger, trans. David McLintock (Cambridge: Cambridge University Press, 1982). 
Oestreich, Gerhard. Antiker Geist und moderner Staat bei Justus Lipsius (1547-1606).

Der Neustoizismus als politische Bewegung, ed. Nicolette Mout (Göttingen:

Vandenhoeck \& Ruprecht, 1989).

Parker, Geoffrey. The Military Revolution: Military Innovation and the Rise of the West, 1500-1800, $2^{\text {nd }}$ edn. with further revision (Cambridge: Cambridge University Press, 2001).

Pečar, Andreas. "Friedrich der Große als Autor: Plädoyer für eine adressatenorientierte Lektüre seiner Schriften.” In Friedrich der Große - eine perspektivische Bestandsaufnahme. Beiträge des ersten Colloquiums in der Reihe „Friedrich300“vom 28./29. September 2007, eds. Michael Kaiser and Jürgen Luh (http://www.perspectivia.net/content/publikationen/friedrich300-colloquien/friedrichbestandsaufnahme/pecar_autor, last accessed 19 June 2021).

Pečar, Andreas. "Selbstinszenierung auf Kosten der Dynastie? Friedrich II. als Autor der 'Denkwürdigkeiten des Hauses Brandenburg'.' In Friedrich der Große und die Dynastie der Hohenzollern: Beiträge des fünften Colloquiums in der Reihe „Friedrich300“ vom 30. September / 1. Oktober 2011, eds. Michael Kaiser and Jürgen Luh (http://www.perspectivia.net/content/publikationen/friedrich300colloquien/friedrich-dynastie/pecar_geschichtsschreibung, last accessed 17 June 2021).

Pečar, Andreas. Autorität durch Autorschaft? Friedrich II. als Militärschriftsteller (Halle an der Saale: Universitätsverlag Halle-Wittenberg, 2013).

Pečar, Andreas. Die Masken des Königs. Friedrich II. von Preußen als Schriftsteller (Frankfurt am Main, New York: Campus Verlag, 2016).

Plutarch. Les vies des hommes illustres, trans. André Dacier. 10 vols. (Amsterdam: Zacharie Chatelain, 1735).

Politische Correspondenz Friedrich's des Grossen. 46 vols. (Berlin: Verlag von Alexander Duncker, 1879-1939). 
Posner, Max, ed. "Frédéric II. Histoire de Mon Temps (Redaktion von 1746)." Publicationen aus den K. preussischen Staatsarchiven 4 (1879), 143-499.

Preuss, Johann D. E., ed. Euvres de Frédéric le Grand. 30 vols. (Berlin: R. Decker, 1846-56).

Puységur, Jacques-François de Chastenet de. Art de la guerre par principes et par règles. 2 vols. (Paris: Charles-Antoine Jombert, 1748).

Quimby, Robert S. The Background of Napoleonic Warfare: The Theory of Military Tactics in Eighteenth-Century France (New York: Columbia University Press, 1957).

Quincy, Charles Sevin, marquis de. Histoire militaire du règne de Louis le Grand, roy de France. 7 vols. (Paris: Denis Mariette; Jean-Baptiste Delespine; Jean-Baptiste Coignard, 1726).

Raeff, Marc. The Well-Ordered Police State: Social and Institutional Change Through Law in the Germanies and Russia, 1600-1800 (New Haven, CT, and London: Yale University Press, 1983).

Roberts, Michael. The Military Revolution, 1560-1660: An Inaugural Lecture Delivered before the Queen's University of Belfast (Belfast: Marjory Boyd, 1956).

Roche, Helen. "The Peculiarities of German Philhellenism.” The Historical Journal 61 (2018), 541-60.

Röhm, Hannelore, and Sabine Scheidler. "Die Bibliotheken Friedrichs des Grossen.” In Friederisiko - Friedrich der Grosse. Die Ausstellung, ed. Generaldirektion der Stiftung Preußische Schlösser und Gärten Berlin Brandenburg (Munich: Hirmer Verlag, 2012), 322-7. 
Rohr, Friedrich Moritz von. Des Herrn Grafen Turpin von Crisse, Brigadiers unter der französischen Armee und Mestre du Camp über ein Husaren Regiment, Versuche über die Kriegskunst. 2 vols. (Potsdam: Johann George Bauer, 1756).

Rollin, Charles. Histoire ancienne des Égyptiens, des Carthaginois, des Assyriens, des Babyloniens, des Mèdes et des Perses, des Macédoniens, des Grecs. 13 vols.

(Amsterdam: J. Wetstein and G. Smith, 1730-9).

Sachse, Ullrich. Cäsar in Sanssouci. Die Politik Friedrichs des Großen und die Antike (Munich: Allitera Verlag, 2008).

Santa Cruz de Marcenado, marquis de. Réflexions militaires et politiques, trans. de Vergy. 4 vols. (The Hague: Jaques van den Kieboom, 1739).

Saxe, Maurice de. Les Rêveries, ou Mémoires sur l'art de la guerre, ed. Zacharie de Pazzi de Bonneville (The Hague: Pierre Gosse, 1756).

Schieder, Theodor. Friedrich der Große. Ein Königtum der Widersprüche (Frankfurt am Main: Propyläen Verlag, 1983).

Shapin, Steven. The Scientific Revolution, Paperback edn. (Chicago, IL, and London: The University of Chicago Press, 1998).

Showalter, Dennis E. The Wars of Frederick the Great (London and New York: Longman, 1996).

Sösemann, Bernd, and Gregor Vogt-Spira, eds. Friedrich der Große in Europa. Geschichte einer wechselvollen Beziehung. 2 vols. (Stuttgart: Franz Steiner Verlag, 2012).

Starkey, Armstrong. War in the Age of Enlightenment, 1700-1789 (Westport, CT, and London: Praeger, 2003). 
Storring, Adam L. Frederick the Great and the Meanings of War, 1730-1755,

Unpublished PhD Dissertation (Faculty of History, University of Cambridge, 2017 https://www.repository.cam.ac.uk/handle/1810/277782).

Storring, Adam L. “"The Age of Louis XIV': Frederick the Great and French Ways of War." German History 38 (2020), 24-46.

Strachan, Hew. European Armies and the Conduct of War (London: George Allen \& Unwin, 1983).

Strachan, Hew, and Sibylle Scheipers, eds. The Changing Character of War (Oxford: Oxford University Press, 2011).

Tharau, Friedrich-Karl. Die geistige Kultur des preußischen Offiziers von 1640 bis 1806 (Mainz: v. Hase \& Koehler Verlag, 1968).

Toman, Rolf, ed. Baroque: Architecture, Sculpture, Painting, trans. Paul Aston, Phil Greenhead, Christine Shuttleworth (Königswinter: Könemann, 2004).

Tribe, Keith. Governing Economy: The Reformation of German Economic Discourse, 1750-1840 (Cambridge: Cambridge University Press, 1988).

Vauban, Sébastien le Prestre de. De l'attaque et de la défense des places. 2 vols. (The Hague: Pierre de Hondt, 1737-42).

Vertot, René Aubert de. Histoire des révolutions arrivées dans le gouvernement de la République romaine, $3^{\text {rd }}$ edn. 3 vols. (The Hague: Henri Scheurleer, 1724).

Voltaire. La Henriade, new edn. (London: Hierome Bold Truth, 1730).

Voltaire. Le siècle de Louis XIV. 2 vols. (Berlin: C. F. Henning, 1751).

Volz, Gustav Berthold, ed. Die politischen Testamente Friedrichs des Grossen (Berlin: Verlag von Reimar Hobbing, 1920). 
Wilson, Peter H. Absolutism in Central Europe (London and New York: Routledge, 2000).

Wilson, Peter H. Europe's Tragedy: A History of the Thirty Years War (London: Allen Lane, 2009). 